\title{
Lucrative future of microalgal biofuels in Pakistan: a review
}

\author{
Maleeha Manzoor $^{1} \cdot$ Fouzia Tabssum $^{1} \cdot$ Hira Javaid $^{1} \cdot$ Javed Iqbal Qazi $^{1}$
}

Received: 3 February 2015 / Accepted: 26 June 2015/Published online: 23 October 2015

(c) The Author(s) 2015. This article is published with open access at Springerlink.com

\begin{abstract}
Pond-grown microalgae have been considered as feedstocks for production of biodiesel. Various natural habitats and man-made environments can be exploited to cultivate microalgae without utilizing arable land which is already decreasing due to urbanization and industrial development. Suitable temperature, solar illumination and availability of phosphorus and nitrogen-rich organic wastes result in algal blooms in stagnant water and river bank's associated pools in many regions including Pakistan. However, for practical application different land areas and effluents of varying natural and man-influenced environments are to be screened for promoting growth and fat-rich body composition of microalgal biomass. Lessons from well-established science of continuous culturing of bacteria can be applied for the open systems with provisions of semi-controlled physico-chemical conditions. In situ microalgal cultivation ponds may be declared mandatory for suitable industries and they can also be cultivated along the banks of rivers. Such efforts will lead to the production of biodiesel, environmental management of effluents and usage of the oil extracted/defatted algal biomass as animal feed supplement. The triad of biofuel production, bioremediation of suitable effluents and provision of animal feed/its supplement would obviously achieve economical feasibility. Different prospects of microalgal cultivation in different localities of Pakistan are discussed with reference to profitable investments.
\end{abstract}

Published in the Special Issue "Energy, Environment, Economics and Thermodynamics".

Javed Iqbal Qazi

qazi.zool@pu.edu.pk

1 Microbial Biotechnology Lab, Department of Zoology, University of the Punjab, Lahore 54590, Pakistan
Keywords Biodiesel - Microalgae cultivation ponds . Environmental management $\cdot$ Reducing eutrophication . Oleaginous microalgae form Pakistan · Freshwater algal growth for biofuel

\section{Introduction}

From domestic level appliances through transportation to industrial-scale operations, different forms of fuels are indispensable for modern life. The needs are being accomplished presently with fossil fuel resources which are depleting very rapidly. Besides consumption of the fossil fuels, extensive usage is not only rapidly depleting them but is seriously causing environmental degradation, health problems and even climatic change globally. The non-renewable fossil fuels present consumption rates and increasing costs of petro-chemicals demand alternative energy resources [1-7].

Success of any biotechnological process largely depends upon continuous supply of feedstock(s) at affordable cost. The processes become further profitable when the substrate resources(s) are derived from wastes of the targeted primary products. Any process qualifying this triad of the parameters would be promising to develop a biotechnological process. Freshwater microalgal growth employing domestic and agro/food industrial effluents can make the biodiesel productions economically appealing. It is not unusual to observe different areas of Pakistan in which after rains, the ditches and small ponds in the towns and villages become fully green within a week. Many oleaginous microalgal species are being reported from Pakistan, which can further be cultivated/processed for oil production. The regional and nutritional aspects favor for establishing cultivation zones of microalgae in many areas of the 
country. Oleaginous microalgae can accumulate triglycerols as storage lipids up to $50 \%$ of their dry cell weight, especially under adverse environmental conditions including photo-oxidative stress. Above 35,000 species of microalgae have been recognized [8] and many of them are able to produce and accumulate lipid contents accounting for $20-50 \%$ of their total biomass which makes them noticeable for biofuel production [9, 10]. Amounts of oil deposition in some species occur so high that the biomass can be processed for oil extraction for transportation fuels [11]. Several species/strains of microalgae could yield more than that of oil crops [9].

\section{Microalgae as renewable feedstock for biofuel}

A constant supply of feedstock is a major challenge for commercialization of any biotechnological product. Feedstock is also a major contributor towards the overall cost of biodiesel production. Ahmed et al. [12] reported that the feedstock contribution in the total cost of biodiesel production is $75 \%$. Demirbas [13] estimated that feedstock might contribute up to $80 \%$ of the overall cost of biodiesel production. Resultantly, feedstock selection and process development to utilize a low-cost feedstock production are very important steps for scalable production of biodiesel. Feedstocks for biodiesel must be available in plenty and at low price [14]. Biodiesel production should also be from those feedstocks which must minimize the greenhouse gases and must not compete with other useful food crops [12]. Karmakar et al. [15] reported that due to the less availability of non-edible oils and their alternatives, there must be some diversification of feedstocks for the biodiesel production. Rapidly depleting fossil fuels reserves/resources and geometrically increasing human populations and their comfort demands have shaken the policy makers as well as scientists to search alternative energy sources. Short-term as well as long-term efforts have been focused. Microalgal species have been viewed as biofuel feedstocks which can be raised with minimal inputs, as being photoautotrophic organisms their nutritional demands are simple. Biofuels derived from algae have attained the importance in the past decades. Various types of sustainable and renewable fuels can be derived from microalgae, such as methane [10], biodiesel [16-21] and biohydrogen [22-26]. Microalgal species are ubiquitous that are able to survive in diverse habitat [27, 28]. Being photoautotrophs and like terrestrial plants, microalgae obtain energy from $\mathrm{CO}_{2}$ as carbon source and yield $\mathrm{O}_{2}$ as a byproduct, ultimately increasing their biomass and intracellular deposition of valuable molecules including oils. Upgradation of $\mathrm{CO}_{2}$ and sunlight in the form of synthesis of complex and

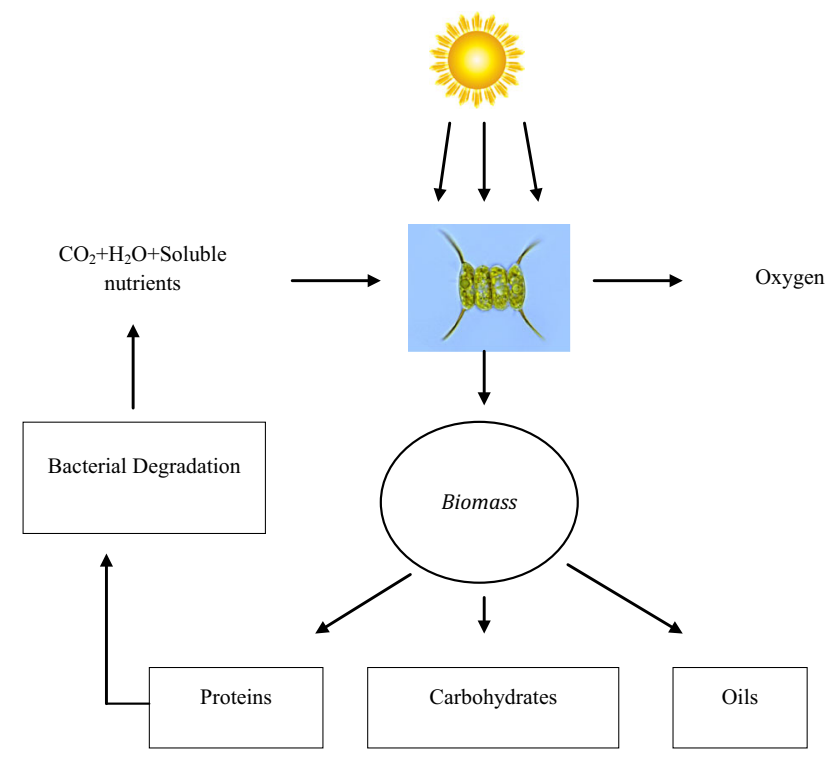

Fig. 1 Sustainable photosynthetic mediated generation of biomolecules in microalgae

of higher energy status biomass and biological molecules may be visualized from Fig. 1 .

It has been documented that microalgae in addition to their well-known autotrophic mode of nutrition may grow heterotrophically/mixotrophically responding to the absence of light and/or presence of organic source [29, 30]. Typically, lipid may accumulate up to $20 \%$ in microbial cells [31]. Lipid accumulation becomes higher in the limited conditions [32]. Depending on algal species, availability and types of nutrients, N:P ratio in algal biomass ranges from 4:1 to 40:1 [33].

Diverse microalgal species may be adapted for cultivation in different environmental conditions. Species inhabitant of local environment(s) can easily be cultivated by mixing the growth conditions and thus should be screened therefore. However, this allowance is not practicable for the first-generation biodiesel feedstocks such as palm oil, rapeseed, soybean and sunflower due to their obvious reason of food competing [34]. Biodiesel yields from microalgae are much higher than the yields obtained from traditional feedstocks. They can produce biodiesel 10-20 times higher than that obtained from vegetable oils [11]. This information can be seen evidently in Table 1 reproduced from [9].

Along with the oil-producing ability, microalgae have many other advantages which are summarized in Table 2 .

\section{Microalgal cultivation in wastes}

Many microalgal species can also be cultivated in wastewaters in addition to their specific nutrient media [47] as these effluents are rich in starch, cellulose, 
Table 1 Oil yield of some biodiesel feedstocks

\begin{tabular}{lll}
\hline Crop & Oil yield (L/ha/year) & Biodiesel productivity (Kg/ha/year) \\
\hline Rape seed & 1190 & 862 \\
Oil palm & 5950 & 4747 \\
Sunflower & 952 & 946 \\
Jatropha & 1892 & 656 \\
Microalgae $^{\mathrm{a}}$ & 58,700 & 51,927 \\
Microalgae $^{\mathrm{b}}$ & 136,900 & 121,104 \\
\hline
\end{tabular}

a Algae contain $30 \%$ oil (/wt) in biomass

b Algae contain $70 \%$ oil (/wt) in biomass [9]

Table 2 Some of the important advantages of microalgae as feedstock for biodiesel production

\begin{tabular}{llll}
\hline S. & Advantage & Reference(s) \\
No. & & \\
\hline 1 & Ability to sequester atmospheric $\mathrm{CO}_{2}$ & {$[35-37]$} \\
2 & Highly efficient in biomass production & {$[38]$} \\
3 & Capable of growing in saline/wastewaters (industrial effluents and municipal sewage) & {$[39]$} \\
4 & Can be cultivated on non-arable land & {$[6,9,40]$} \\
5 & Several microalgal species produce valuable co-products including proteins, natural dyes, antioxidants, pigments, fats, & {$[39,41,42]$} \\
6 & and sugars & They require less labor, are easy to handle and have a short life cycle as compared to other crop oils \\
7 & Residual biomass from the processes can potentially be used as fertilizers, soil amendments, and fish/livestock feed & {$[44-46]$} \\
\hline
\end{tabular}

carbohydrates, hemicellulose, inorganic and organic compounds [48]. Microalgae are very efficient in removal of toxic metals, phosphorus and nitrogen under controlled environmental conditions from wastewaters. They grow naturally in wastewaters and tolerate varying levels of nitrogen and phosphorus during their growth. The cultivation of microalgae may also reduce the risk of harmful outgrowth of phytoplanktons [49]. Selection of the algal species depends on the type of wastewaters where they are intended to be cultivated.

For the production of liquid biofuels, wastewater media serve as a potential source of low-cost substrates [50]. The agro-industrial and municipal wastewaters appear cost effective and promising sustainable means for biofuel production through the cultivation of oleaginous microalgae [5]. Microalgae are in fact, capable of growing efficiently on many types of wastes/wastewaters. Some of frequently available categories of wastewaters, which are being considered to be exploited for low-cost algal cultivations in near future, are discussed below.

\section{Municipal/domestic sewage wastewater}

Municipal wastewaters originate from households, commercial activities and industrial facilities. Such wastewaters are generally characterized with high organic matter, nitrogen and phosphorus. They may also harbor toxic compounds and pathogenic microorganisms. Before considering for reuse or return to the environment, the municipal wastewater is to be treated. Availability and cost effectiveness of municipal wastewater for microalgae growth need no explanations [30, 51]. For removal of phosphorus and nitrogen from municipal wastewater, microalgal cultivation is being most extensively applied [52-55]. Lu et al. [56] reported that cultivating microalgae with municipal wastewaters is not only feasible for the biodiesel production, but also helps in removing nitrogen and phosphorus.

\section{Agricultural/industrial wastewaters}

In fact, any waste which may yield organic carbon source and/or $\mathrm{CO}_{2}$ for mixotrophic and/or autotrophic cultivation of microalgae can be exploited for biodiesel production. Additional beneficial characteristics of such wastes would be the minerals needed by the growing microalgae. Several workers have documented different agro/industrial wastewaters for successful cultivation of microalgae. Agwa et al. [57] investigated different animal wastes (goat, poultry, grass cutter, cow and pig) as growth medium for Chlorella sp. There was significant increase in the lipid contents of the microalgae and highest biomass yield under mixotrophic conditions which are less expensive to maintain. Mata et al. [58] analyzed the growth of Scenedesmus obliquus for 12 days in brewery wastewaters for biodiesel production. Results were average lipid contents of $27 \%$ of 
dry weight of biomass. Various other food industrial/agricultural residues/wastes have been employed for maximum microalgal biomass and biodiesel production like rice straw hydrolysate being utilized for growing Chlorella pyrenoidosa [54], orange peels extract for Chlorella vulgaris [59] and sugarcane bagasse for Scenedesmus acutus [60].

\section{Artificial wastewaters}

Artificial wastewater is actually a synthetic medium, which consists of those inorganic nutrients present in real wastewaters, but lacks toxic chemicals and microbes, and characteristics of real wastewaters. Kong et al. [61] employed Chlamydomonas reinhardtii in artificial wastewaters as media and was monitored for 10 days. Results showed high biomass and lipid accumulations and effective removal of nitrogen and phosphorus.

\section{Potential waste/low-cost substrates in Pakistan}

Pakistan is characterized with large agricultural and livestock sector and resultantly copious quantities of agriculture and crop residues such as rice husk, wheat straw, cane trash, cotton sticks, bagasse, municipal solid waste, animal residue and poultry litter are produced whose disposal is a big challenge [62]. Annual production of various crops and their residue availability in Pakistan is shown in Table 3 reproduced from Bhutto et al. [63]. Availability of waste biomass is also widespread in urban areas of Pakistan where over 50,000 tons of municipal wastes, 225,000 tones of crop residue and over 1 million tones of animal manure productions/day are estimated. Solid waste composition in Pakistani cities is shown in Table 4 [64].

Additionally, for towns and suburb areas of various locations within the country, sanitary conditions are very poor. Resultantly, rain water and the normal domestic sewage carry lot of organic loads which occasionally are withheld in low land areas or small ponds. In such waters, algal blooms are frequently observed, especially after rainy

Table 3 Annual production of various crops and their residues in Pakistan [63]

\begin{tabular}{lll}
\hline Major crop & Annual production & Residue \\
\hline Sugarcane & 49,373 & Bagasse, leaves and tops \\
Dry chilly & 1877 & Stalks \\
Rice & 6883 & Husks, Straws, Stalks \\
Wheat & 23,864 & Pod, Stalks \\
Cotton & 3000 & Boll shell, Husk, Stalks \\
Maize & 296 & Cobs, Stalks \\
Barley & 82 & Stalks \\
Bajra & 470 & Cobs, Husks, Stalks \\
\hline
\end{tabular}

Table 4 Urban solid waste composition in Pakistan (\%) [64]

\begin{tabular}{ll}
\hline Composition of waste & Percentage (\%) \\
\hline Food waste & $8.4-21$ \\
Leaves, grass, fodder, straw & $10.2-15.6$ \\
Fines & $29.7-47.5$ \\
Recyclables & $13.6-23.55$ \\
\hline
\end{tabular}

season. This indicates that the areas drained by the rain water contain sufficient supply of minerals and other nutrients required for the successive growth of algae. Therefore, it is tempting to speculate that controlled/desired cultivation of suitable algae/microalgae in the domestic/agricultural runoff may solve the problems of the waste management as well as biodiesel supply.

\section{Microalgal species' diversity in Pakistan}

As mentioned earlier, algae are a diverse family of photosynthetic eukaryotic species. Most of them are aquatic. Algal species can be classified into several major groups such as green algae, diatoms, blue green and golden algae. A reasonable number of microalgal species from freshwater have been documented for their oil depositing potential as well as for their successful cultivation in employing different wastes. In Pakistan although the cultivation of oleaginous microalgae is in its infancy, however, several species documented in literature for the above-mentioned potentials are found in different habitats in Pakistan. A brief review of documented microalgal freshwater is given in Table 5.

However, depending upon the habitat diversity available in this country and scarcity of research efforts for describing the microalgal diversity there is much likelihood that more oleaginous freshwater microalgal species would be identified in future.

\section{Prospects of cost effective microalgal cultivation}

Tredici [74] described that locations suitable for mass cultivation of algae around the world include: Central Africa, Southern Asia, South Eastern Australia, Southern part of South and North America, Caribbean Islands, also depicted in Fig. 2 [75]. The temperature in most of these areas does not drop below $15^{\circ} \mathrm{C}$ throughout the year and climate is therefore warmer. Such climatic conditions are ideal for algal growth in closed and open pond systems. As these countries are developing therefore they could strongly benefit from establishing algal industries. Algae farming will create new jobs concomitant with transfer of 
Table 5 Some of the oleaginous freshwater microalgal species reported from Pakistan

\begin{tabular}{lll}
\hline Species & Distribution (Pakistan) & Reference(s) \\
\hline Chlorella vulgaris & 1. Manghopir euthermal springs, Karachi & {$[65]$} \\
& 2. Lahore, Pasrur, Sialkot, Punjab & {$[66]$} \\
& 3. Keenjhar lake, Thatta, Sindh & {$[67]$} \\
& 4. District Swat, K. P. K & {$[68]$} \\
Botryococcus braunii & Keenjhar lake, Thatta, Sindh & {$[67]$} \\
Scenedesmus obliquus & District Swat, K. P. K & {$[68]$} \\
Scenedesmus quadricauda & 1. Manghopir euthermal springs, Karachi & {$[65]$} \\
& 2. Keenjhar lake, Thatta, Sindh & {$[67]$} \\
Scenedesmus dimorphus & 3. District Swat, K. P. K & {$[68]$} \\
1. Keenjhar lake, Thatta, Sindh & {$[67]$} \\
Rhizocolonium hieroglyphicum & Gilgit & {$[68]$} \\
Nannochloropsis oculata & Southern Pakistan (Karachi), Lyari river and Kalari river & {$[69]$} \\
Scenedesmus acuminatus & Keenjhar lake, Thatta, Sindh & {$[67]$} \\
Chlorella pyrenoidosa & 1. Haleji lake & {$[71]$} \\
Scenedesmus bijuga & 2. Keenjhar lake, Thatta, Sindh & {$[67]$} \\
Euglena viridis & Keenjhar lake, Thatta, Sindh & {$[67]$} \\
Chlamydomonas sp. & Between Shahdara and Gujranwala & {$[72]$} \\
\hline & Tannery effluents (Kasur) & {$[73]$} \\
\hline
\end{tabular}

technologies to developing countries [76]. Abundant sunlight is the basic requirement for algal cultivation on suitable sites. This is definitely an important consideration since biomass yield is directly linked to the insolation. A study carried out on the global evaluation of microalgal biofuels potential also suggested that Cambodia, Egypt, India, Australia, Brazil, Saudi Arabia and Kenya are expected to give maximum average annual lipid yields ranging 24-27 $\mathrm{m}^{3} /$ ha year. [77]. Average solar radiations received by two Indian States UNA, HP and Chennai is around $5.3 \mathrm{KW} / \mathrm{h} / \mathrm{m}^{2} /$ day. High solar insolations in these areas provide ideal combination for the cultivation of algae in open ponds. On average, $35 \mathrm{ml} / \mathrm{m}^{2} /$ day and $75 / \mathrm{m}^{2} /$ day of oil yield and biomass would be possible for said locations [78]. For Hawaii condition Huntley and Redalji [79] estimated the average annual productivity of $50 \mathrm{~g} / \mathrm{m}^{2} /$ day. Similarly at Israel for a small scale pilot pond system, the average productivity is reported up to $20 \mathrm{~g} / \mathrm{m}^{2} /$ day [80].

Main areas of energy consumption in Pakistan are industrial, transport, domestic appliances, agricultural,

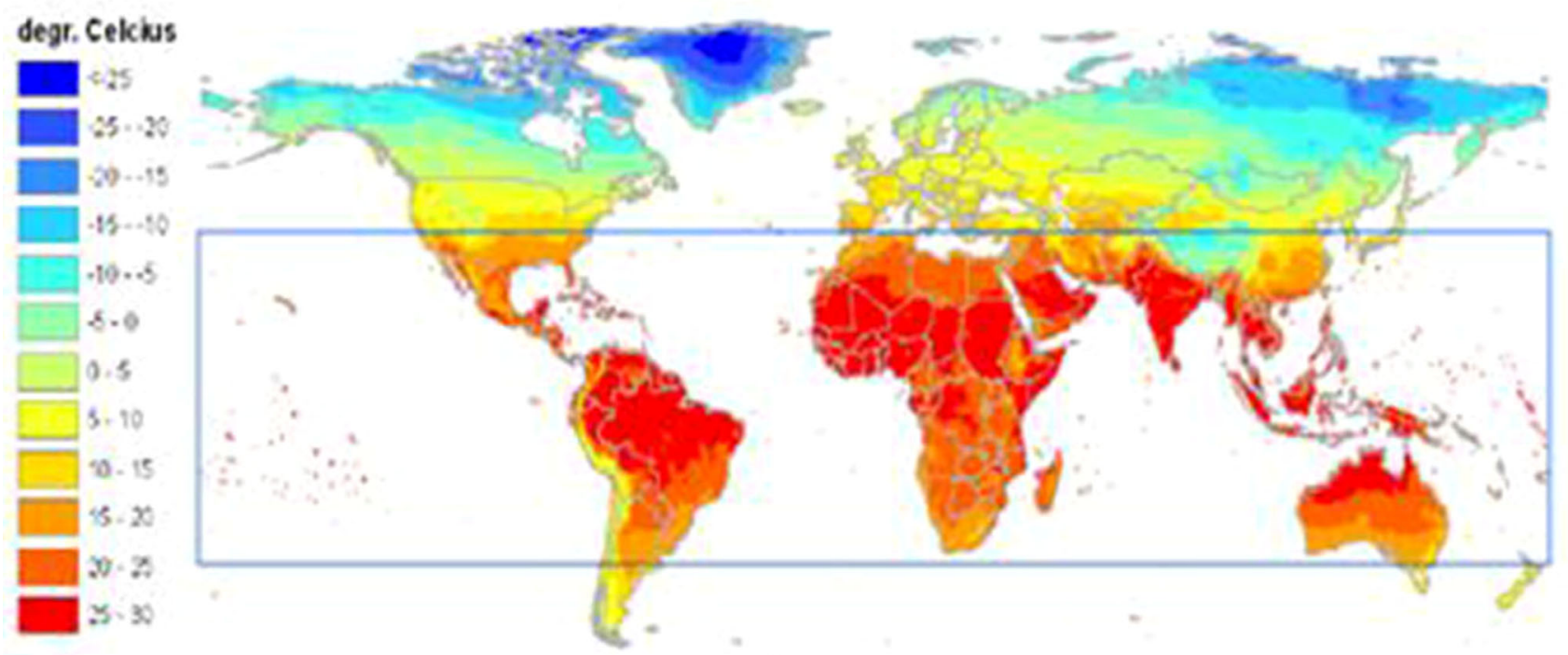

Fig. 2 Map showing suitable sites for algal growth [75] 


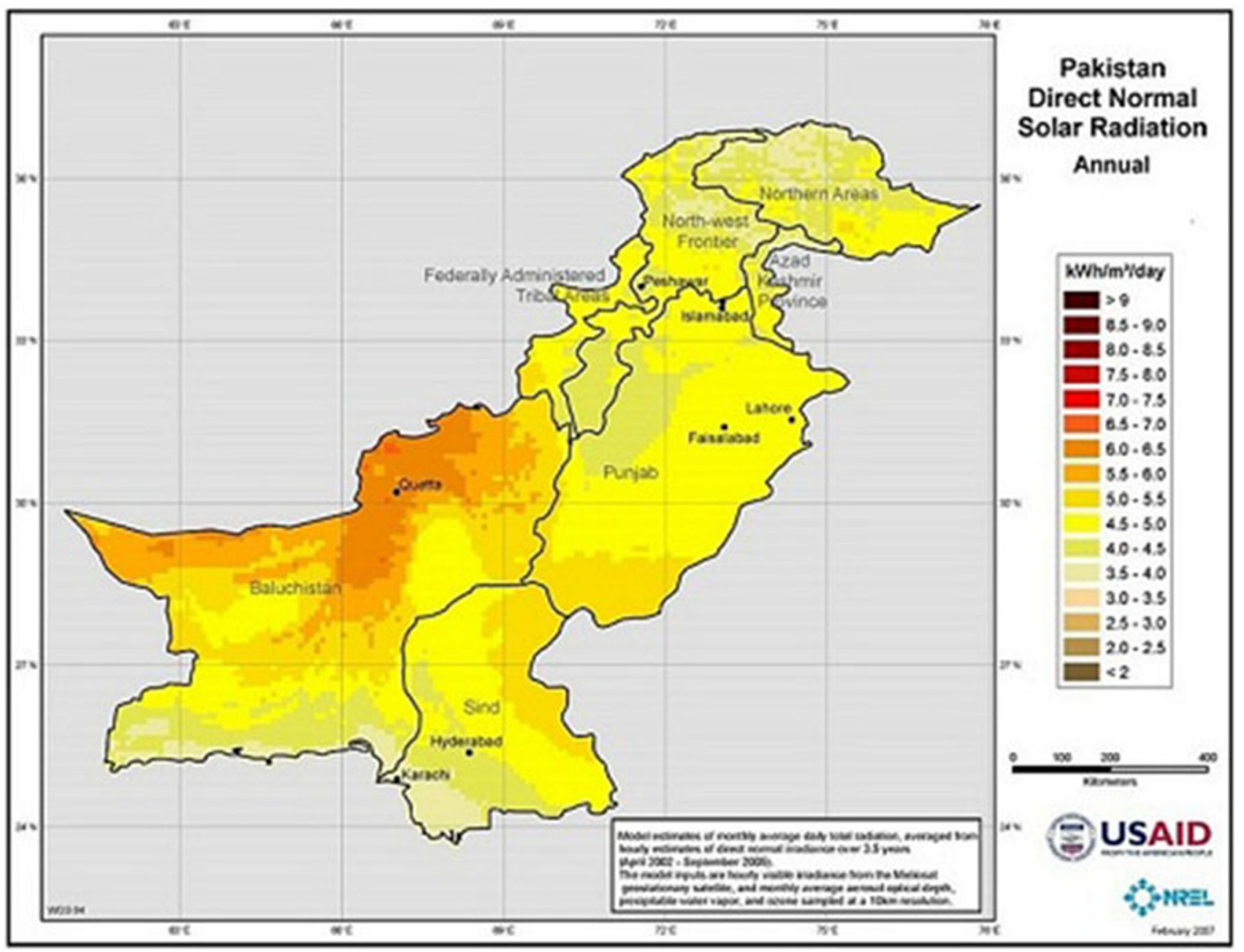

Fig. 3 Solar map of Pakistan developed by NREL and USAID [87]

commercial and many other government sectors. Need of energy is growing up to $10 \%$ every year in Pakistan [81]. Like other countries almost all energy needs are met with the consumption of fossil fuels while Pakistan has abundance of renewable energy resources which need proper exploitation [82]. Owing to the abundant availability of low-cost feedstock for microalgal cultivation, biodiesel production has a lucrative future in Pakistan. Projects on biofuels look quite feasible with booming future in Pakistan. It is to be noticed that raw material which can serve excellent feedstocks for the microalgal biodiesel production is abundantly available in this country. Eutrophication is a very commonly encountered phenomenon of lentic waters, especially for those receiving urban or organic wastes rich agro/food industrial effluents in Pakistan. Algal growth may start at the rim of littoral zone and latter may cover the limnetic zone too. Even in the case of streams and river banks, presence of associated pools of varying sizes full with algal blooms are not uncommon for the downstream locations in many cities of Pakistan. The algal blooms in stagnant waters and rivers are due to the suitable temperature and solar illumination prevailing throughout the year in most parts of the country. Geographically Pakistan lies in the world's greatest solar insulation area, receiving high intensity of solar radiations due to favorable climatic conditions $[83,84]$. To identify solar potential of the country the solar climate of Pakistan has been elaborately studied by Raja [85]. Potential of solar energy in Pakistan has been estimated at over 100,000 MW [86]. An average of $5.5 \mathrm{KW} / \mathrm{m}^{2}$ of the solar radiations is received by the country during 300 or more clear days per annum [81, 84]. Solar map (Fig. 3) of Pakistan reflects that many locations of the country are blessed with excellent solar insulation ranging from 5 to $7 \mathrm{kWh} / \mathrm{m}^{2} /$ day [87].

The development and harvesting of microalgae in Pakistan is thus very suitable as it is located on solar belt. The vast solar insulation potential must be exploited for sustainable development in the country through overcoming the energy shortage and for preparing to cope with the coming climatic changes. After rains, the ditches and small 
ponds in the towns and villages become fully green within a week. Such habitats provide eutrophication locations which can be exploited or managed for cultivating feedstocks for biofuel production. Regarding ecological aspects of such systems, Smith et al. [88] described that having a high surface-to-volume ratio a typical eutrophic lake is characterized with abundance of nutrients, specifically nitrogen and phosphorus. Such conditions will obviously stimulate heavy growth of algae and/or other aquatic plants.

Eutrophication of freshwater habitat, previously an established ecological stress for aquatic fauna can now be looked as a resource for the production of biodiesel but essentially in a scientifically regulated manner. Importance of microalgal cultivation for obtaining biofuels and biomaterials is well established. Smith et al. [88] demonstrated that key principles of ecology can be applied to design pondbased microalgal cultivation systems for the production of biodiesel fuels. Scott et al. [89] discussed that microalgae offer great potential of biodiesel production, however, processes still far from being commercially viable. Algal biomass production and deposition of fuel molecules within the algal cell need optimization for a given cultivation system. However, for practical application different land areas and effluents of varying natural and man-influenced environments are to be screened for promoting growth and fat-rich body composition of microalgae growth. For this ponds receiving the effluents are to be established with controlled dilutions rates for continuous/sustainable provision of oleaginous algal biomass. Lessons from well-established science of continuous culturing of bacteria can be applied for the open systems with provisions of semi-controlled physico-chemical conditions. Such endeavors are likely to address three major issues of this age, i.e., provisions of suitable transport fuels, environmental management and animal feed in a scalable and commercially viable way.

Owing to the above notion, Demirbas [90] described that costs of biofuel production vary widely and depend on scale of production, conversion process and regional attributes regarding nature and supply of feedstock. In the near future, algae will prove to be most important biofuel source. Microalgae represent best source of renewable biodiesel with potential of meeting global demands for transport fuels. The notion of regional influence on cost of biofuel production indicated above favors for designing suitable microalgal cultivation facilities with concomitant biological treatment effluents/urban-influenced streams/rivers water in Pakistan. Demirbas [90] commented rightly that the earth atmosphere was filled with $\mathrm{CO}_{2}$ billion of years ago when no life on earth was recordable. Cyanobacteria and algae probably were the first to imprint their signatures on the earth. These pioneering photosynthetic organisms consumed up the atmospheric $\mathrm{CO}_{2}$ and started to replace it with $\mathrm{O}_{2}$.
Resultantly, aerobic life evolved on earth. It appears that threat of global warming will also be resolved once again by the smallest photosynthetic organisms.

\section{Construction of effluents withholding ponds}

Following criteria should be met by the site being selected for algal cultivation:

(a) Land topography.

(b) Temperature, humidity, evaporation and precipitation.

(c) Availability of sunlight throughout the year.

(d) Availability of water, carbon source and nutrients [91].

For above notion, obviously sustainable and affordable design for construction of effluents withholding ponds at suitable places is to be worked out. Any open system filled with suitable water supply containing algal growth-sustaining nutrients may allow the growth of an unwanted species of microalgae which may be of little value regarding its lipid accumulation ability. While in the open cultivation ponds concept of aseptic environment is beyond the level of consideration. Specific inoculations may become successful or may not compete the contaminating algal species. Another part of the problem to be taken proper care of regards the nature of effluents and their proper dilutions. The industrial effluents should be withheld in ponds and then following the harvesting of microalgal crops the water should be removed to the natural system. Alternatively, the urban/agri/food industrial waste-influenced downstream waters can be channeled into the banks associated ponds/shallow channels for reducing their N/P contents and obtaining the algal crops. For countries such as Pakistan, experiencing high levels of socio-economic transition, both routes of the water treatments and the algal biomass cultivation is adopted together. For these routes as well as for having the cultivation of suitable microalgal species, a workable layout is shown in Fig. 4.

\section{Conclusion}

In conclusion, climatic zones of Pakistan, nature and abundance of agro/food industrial wastes and the wastes containing effluents and endogenous microalgal cultivatable species give much hope to develop bioprocess for efficient biodiesel and animal feed/supplement production in economically viable fashions. Conversion of wastes into biofuels and biomass of animal nutritional importance cannot be overemphasized for developments amongst the less effluent populations. Besides alleviating poverty in 
Fig. 4 Schematic layout of two routes of cultivating microalgae for concomitant production of biodiesel and treatment of waste waters. However, both the routes are applicable for rendering used waters as safe discharge to downstream river/ stream waters of specific attributes

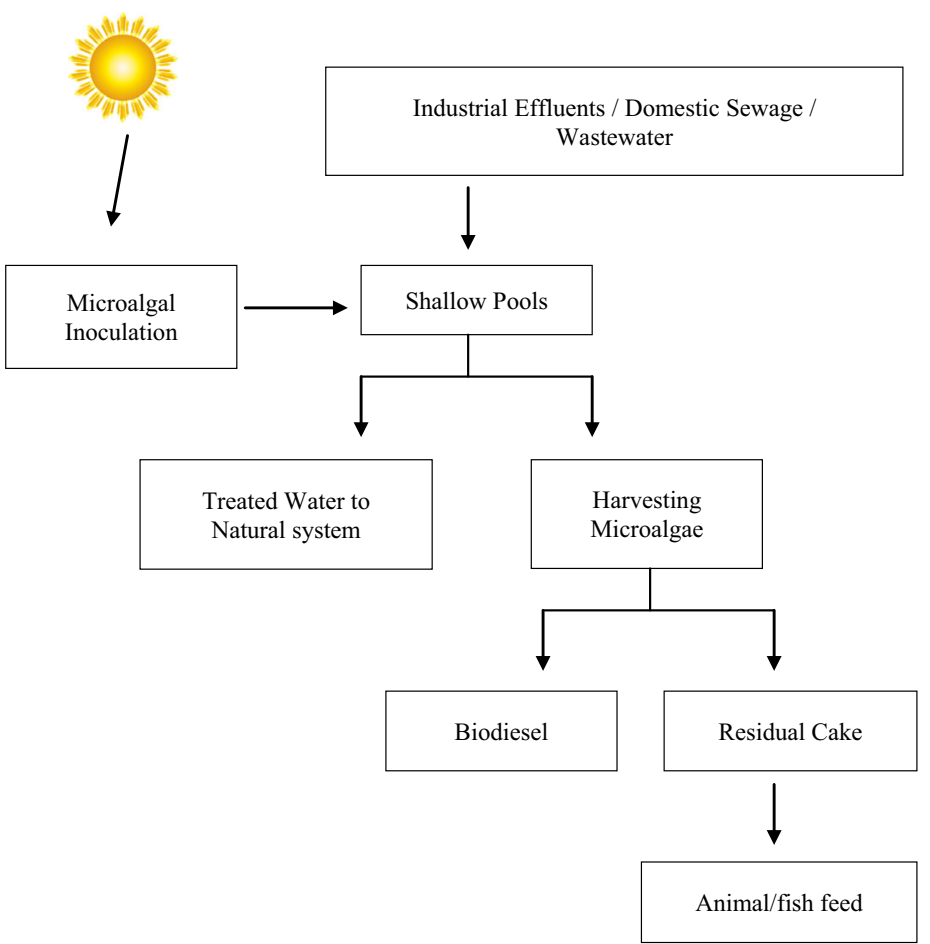

Route I: Designing microalgal cultivation for in situ processing of domestic/ industrial effluents.

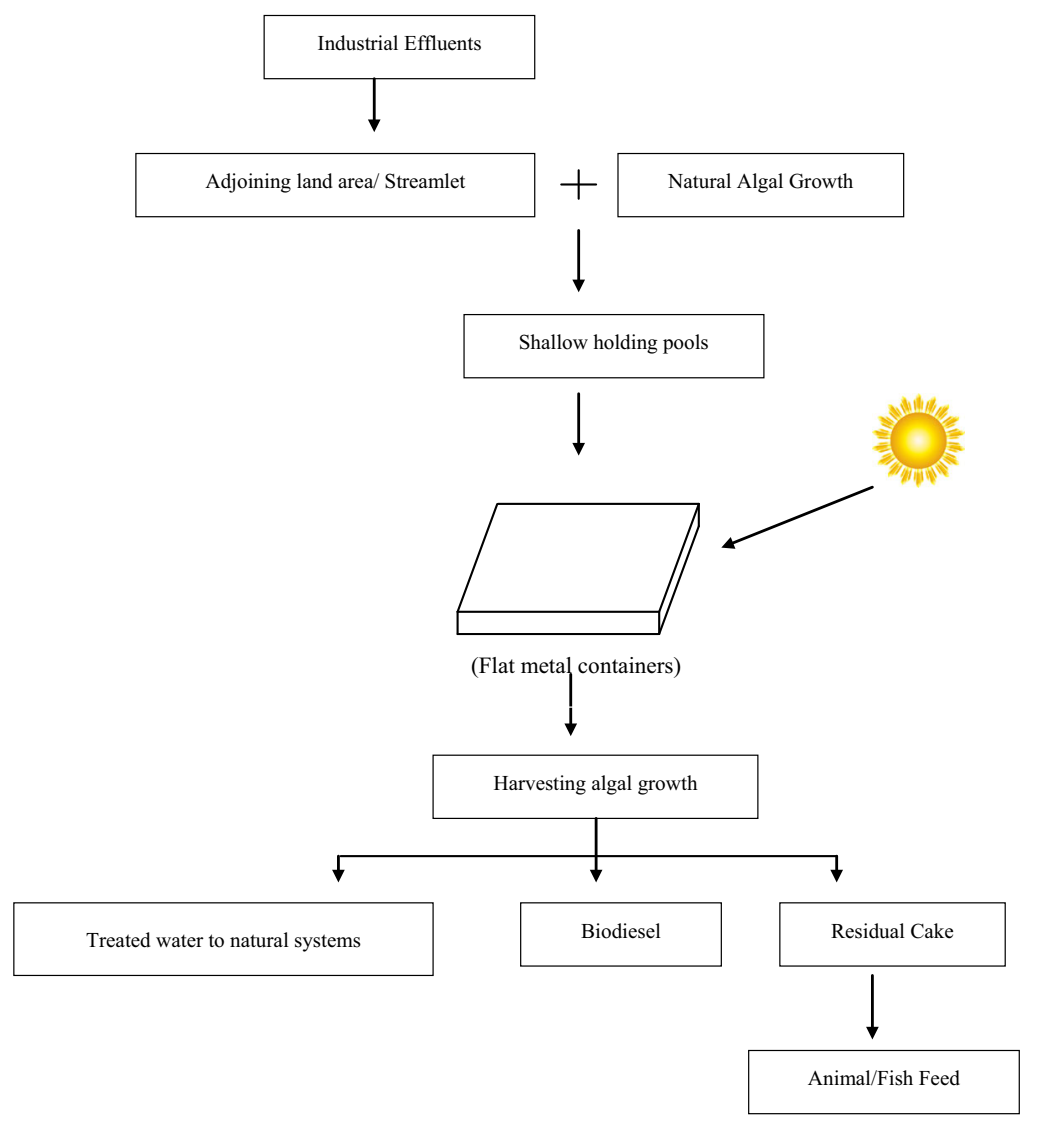

Route II: Processing of algal contaminated and other suitable effluents for biodiesel production and wastewater treatment. 
developing countries, environmental health officials will also be supportive to the development of such processes. The treated waters characterized with less BOD will be valuable for irrigational purposes.

Open Access This article is distributed under the terms of the Creative Commons Attribution 4.0 International License (http://crea tivecommons.org/licenses/by/4.0/), which permits unrestricted use, distribution, and reproduction in any medium, provided you give appropriate credit to the original author(s) and the source, provide a link to the Creative Commons license, and indicate if changes were made.

\section{References}

1. Yuan, Q.: Advances in Energy Chemistry. Chemical Industrial Press, Beijing (2005)

2. Esper, B., Badura, A., Roegner, M.: Photosynthesis is a power supply for (bio) hydrogen production. Trends Plant Sci. 11, 543 (2006)

3. Kouroussis, D., Karimi, S.: Alternative fuels in transportation. Bull. Sci. Technol. Soc. 26, 346-355 (2006)

4. Hill, J., Nelson, E., Tilman, D., Polasky, S., Tiffany, D.: Environmental, economic, and energetic costs and benefits of biodiesel and ethanol biofuels. Proc. Natl. Acad. Sci. USA 103, 11206-11210 (2006)

5. Pittman, J.K., Dean, A.P., Osundeko, O.: The potential of sustainable algal biofuel production using wastewater resources. Bioresour. Technol. 102, 17-25 (2011)

6. Demirbas, A.: Progress and recent trends in biodiesel fuels. Energy Convers. Manag. 50, 14-34 (2009)

7. Urbaniec, K., Grabarczyk, R.: Raw materials for fermentative hydrogen production. J. Clean. Prod. 17, 959-962 (2009)

8. Cardozo, K.H., Guaratini, T., Barros, M.P., et al.: Metabolites from algae with economical impact. Comp. Biochem. Physiol. Part C Toxicol. Pharmacol. 146, 60-78 (2007)

9. Spolaore, P., Joannis-Cassan, C., Duran, E., Isambert, A.: Commercial application of microalgae. J. Biosci. Bioeng. 101, 87-96 (2006)

10. Chisti, Y.: Biodiesel from microalgae. Biotechnol. Adv. 25, 294-306 (2007)

11. Gouveia, L., Oliveira, A.C.: Microalgae as a raw material for biofuels production. J. Ind. Microbiol. Biotechnol. 36, 269-274 (2009)

12. Ahmad, A.L., Yasin, N.H.M., Derek, C.J.C., Lim, J.K.: Microalgae as a sustainable energy source for biodiesel production: a review. Renew. Sustain. Energy Rev. 15, 584-593 (2011)

13. Demirbas, A.: Importance of biodiesel as transportation fuel. Energy Policy 35, 4661-4670 (2007)

14. Lim, S., Teong, L.K.: Recent trends, opportunities and challenges of biodiesel in Malaysia: an overview. Renew. Sustian. Energy Rev. 14, 938-954 (2010)

15. Karmakar, A., Karmakar, S., Mukherjee, S.: Properties of various plants and animals feedstocks for biodiesel production. Bioresour. Technol. 101(19), 7201-7210 (2010)

16. Roessler, P.G., Brown, L.M., Dunahay, T.G., Heacox, D.A., Jarvis, E.E., Schneider, J.C., et al.: Genetic-engineering approaches for enhanced production of biodiesel fuel from microalgae. ACS Symp. Ser. 566, 255-270 (1994)

17. Sawayama, S., Inoue, S., Dote, Y., Yokoyama, S.Y.: $\mathrm{CO}_{2}$ fixation and oil production through microalga. Energy Convers. Manag. 36, 729-731 (1995)
18. Dunahay, T.G., Jarvis, E.E., Dais, S.S., Roessler, P.G.: Manipulation of microalgal lipid production using genetic engineering. Appl. Biochem. Biotechnol. 57-58, 223-231 (1996)

19. Sheenan, J., Dunahay, T., Benemann, J., Roessler, P.: Look back at the U.S. department of energýs aquatic species program: biodiesel from algae, pp. 1-328. National Renewable Energy Laboratory, Midwest Research Institute, Golden (1998)

20. Banerjee, A., Sharma, R., Chisti, Y., Banerjee, U.C.: Botryococcus braunii: a renewable source of hydrocarbons and other chemicals. Crit. Rev. Biotechnol. 22, 245-279 (2002)

21. Gavrilescu, M., Chisti, Y.: Biotechnology-a sustainable alternative for chemical industry. Biotechnol. Adv. 23, 471-499 (2005)

22. Ghirardi, M.L., Zhang, J.P., Lee, J.W., Flynn, T., Seibert, M., Greenbaum, E.: Microalgae: a green source of renewable $\mathrm{H}_{2}$. Trends Biotechnol. 18, 506-511 (2000)

23. Akkerman, I., Janssen, M., Rocha, J., Wijffels, R.H.: Photobiological hydrogen production: photochemical efficiency and bioreactor design. Int. J. Hydrog. Energy 27, 1195-1208 (2002)

24. Melis, A.: Green alga hydrogen production: progress, challenges and prospects. Int. J. Hydrog. Energy 27, 1217-1228 (2002)

25. Fedorov, A.S., Kosourov, S., Ghirardi, M.L., Seibert, M.: Continuous $\mathrm{H}_{2}$ photoproduction by Chlamydomonas reinhardtii using a novel two-stage, sulfate-limited chemostat system. Appl. Biochem. Biotechnol. 121124, 403-412 (2005)

26. Kapdan, I.K., Kargi, F.: Bio-hydrogen production from waste materials. Enzym. Microb. Technol. 38, 569-582 (2006)

27. Falkowski, P.G., Raven, J.A.: Aquatic Photosynthesis. Blackwell Science, Malden (1997)

28. Hu, Q., Sommerfeld, M., Jarvis, E., Ghirardi, M., Posewitz, M., Seibert, M., Darzins, A.: Microalgal triacylglycerols as feedstocks for biofuel production: perspectives and advances. Plant J. 54, 621-639 (2008)

29. Chojnacka, K., Noworyta, A.: Evaluation of growth yield of Spirulina (Arthrospira) sp. growth in photoautotrophic, heterotrophic and mixotrophic cultures. Enzym. Microbial. Technol. 34, 461-465 (2004)

30. Wang, L., Yecong, L., Chen, P., Min, M., Chen, Y., Zhu, J., Ruan, R.: Anaerobic digested dairy manure as a nutrient supplement for cultivation of oil-rich green microalgae Chlorella sp. Bioresour. Technol. 101, 2623-2628 (2010)

31. Benemann, J.R.: Opportunities and challenges in algae biofuels production. A position paper. Algae World 2, 216-226 (2008)

32. Benemann, J.R., Oswald, W.J.: Systems and economic analysis of microalgae ponds for conversion of $\mathrm{CO}_{2}$ to biomass. NASA STI/ Recon Technical Report N. 95, 19554. (1994)

33. Craggs, R.J., Heubeck, S., Lundquist, T.J., Benemann, J.R.: Algal biofuels from wastewater treatment high rate algal ponds. Water Sci. Technol. 63, 660 (2011)

34. Mata, T., Martins, A., Caetano, N.: Microalgae for biodiesel production and other applications: a review. Renew. Sustain. Energy Rev. 14, 217-232 (2010)

35. Campbell, C.J.: The Coming Oil Crisis. Multi-Science Publishing Company and Petroconsultants, S.A Essex, Brentwood (1997)

36. Pokoo-Aikins, G., Nadim, A., El-Halwagi, M.E., Mahalec, V.: Design and analysis of biodiesel production form algae grown through carbon sequestration. Clean Technol. Environ. Policy 12(3), 239-254 (2010)

37. Lam, M.K., Lee, K.T., Mohamed, A.R.: Current status and challenges on microalgae-based carbon capture. Int. J. Greenh. Gas Control 10, 456-469 (2012)

38. Huesemann, M.H., Hausmann, T.S., Bartha, R., Aksoy, M., Weissman, J.C., Benemann, J.R.: Biomass productivities in wild type and pigment mutant of Cyclotella sp. (diatom). Appl. Biochem. Biotechnol. 157(3), 507-526 (2009) 
39. Raja, R., Hemaiswarya, S., Kumar, N.A., Sridhar, S., Rengasamy, R.: A perspective on the biotechnological potential of microalgae. Crit. Rev. Microbiol. 34(2), 77-88 (2008)

40. Brennan, L., Owende, P.: Biofuels from microalgae: towards meeting advanced fuel standards. In: Lee, J.W. (ed.) Advanced Biofuels and Bioproducts, pp. 553-599. Springer, New York (2013)

41. Li, Y., Horsman, M., Wang, B., Wu, N., Lan, C.: Effects of nitrogen sources on cell growth and lipid accumulation of green alga Neochloris oleoabundans. Appl. Microbiol. Biotechnol. 81, 629-636 (2008)

42. Li, Y., Horsman, M., Wu, N., Lan, C.Q., Dubois-Calero, N.: Biofuels from microalgae. Biotechnol. Prog. 24(4), 815-820 (2008)

43. Schenk, P., Thomas-Hall, S., Stephens, E., Marx, U., Mussgnug, J., Posten, C., Kruse, O., Hankamer, B.: Second generation biofuels: high-efficiency microalgae for biodiesel production. Bioenerg. Res. 1(1), 20-43 (2008)

44. Mulbry, W.W., Wilkie, A.C.: Growth of benthic freshwater algae on dairy manures. J. Appl. Phycol. 13, 301-306 (2001)

45. McGinn, P.J., Dickinson, K.E., Bhatti, S., Frigon, J., Guiot, S.R., O'Leary, S.J.: Integration of microalgae cultivation with industrial waste remediation for biofuel and bioenergy production: opportunities and limitations. Photosynth. Res. 109, 231-247 (2011)

46. Breuer, G., Lamers, P.P., Martens, D.E., Draaisma, R.B., Wijffels, R.H.: The impact of nitrogen starvation on the dynamics of triacylglycerol accumulation in nine microalgae strains. Bioresour. Technol. 124, 217-226 (2012)

47. Oswald, W.J., Gotaas, H.B.: Photosynthesis in sewage treatment. Trans. Am. Soc. Civ. Eng. 122, 73-105 (1957)

48. Lara, M.A., Rodríguez-Malaver, J., Rojas, O.J., Hoimquist, O., González, A.M., Bullón, J., Peñaloza, N., Araujo, E.: Black liquor lignin biodegradation by Trametes elegans. Int. Biodeterior. Biodegad. 52, 167-173 (2002)

49. Cai, T., Park, S.Y., Li, Y.: Nutrient recovery from wastewater streams by microalgae: status and prospects. Renew. Sustain. Energy Rev. 19, 360-369 (2013)

50. Woertz, I., Feffer, A., Lundquist, T., Nelson, Y.: Algae grown on dairy and municipal wastewater for simultaneous nutrient removal and lipid production for biofuel feedstock. J. Environ. Eng. 135, 1115-1122 (2009)

51. Nandini, S., Ramírez-García, P., Sarma, S.S.S.: Evaluation of primary and secondary production using waste water as the culture medium. Waste Manag. Res. 28, 928-935 (2010)

52. Bhatnagar, A., Bhatnagar, M., Chinnasamy, S., Das, K.C.: Chlorella minutissima-a promising fuel alga for cultivation in municipal wastewaters. Appl. Biochem. Biotechnol. 161, 523-536 (2010)

53. Ruiz-Marin, A., Mendoza-Espinosa, L.G., Stephenson, T.: Growth and nutrient removal in free and immobilized green algae in batch and semi-continuous cultures treating real wastewater. Bioresour. Technol. 101, 58-64 (2010)

54. Li, Y., Chen, Y., Chen, P., Min, M., Zhou, W., Martinez, B.: Characterization of a microalga Chlorella sp. well adapted to highly concentrated municipal wastewater for nutrient removal and biodiesel production. Bioresour. Technol. 102, 5138-5144 (2011)

55. Chi, Z., Zheng, Y., Jiang, A., Chen, S.: Lipid production by culturing oleaginous yeast and algae with food waste and municipal wastewater in an integrated process. Appl. Biochem. Biotechnol. 165, 442-453 (2011)

56. Lu, Q., Wang, Z., Dong, C.Q., Zhang, Z.F., Zhang, Y., Yang, Y.P., Zhu, X.F.: Selective fast pyrolysis of biomass impregnated with $\mathrm{ZnCl}_{2}$ : furfural production together with acetic acid and activated carbon as by-products. J. Anal. Appl. Pyrolysis 1, 273-279 (2011)

57. Agwa, O.K., Ibe, S.N., Abu, G.O.: Economically effective potential of Chlorella sp. for biomass and lipid production. J. Microbiol. Biotechnol. 2(1), 35-45 (2012)

58. Mata, T.M., Almeida, R., Caetano, N.S.: Effect of the culture nutrients on the biomass and lipid productivities of microalgae Dunaliella tertiolecta. Chem. Eng. Trans. 32, 973-978 (2013)

59. Park, W.K., Moon, M., Kwak, M.S., jeon, S., Choi, G.G., Yang, J.W., Lee, B.: Use of orange peel extract for mixotrophic cultivation of Chlorella vulgaris: Increased production of biomass and FAMEs. Bioresour. Technol. 171, 343-349 (2014)

60. Rattanapoltee, P., Kaewkannetra, P.: Utilization of Agricultural Residues of Pineapple Peels and Sugarcane Bagasse as costsaving raw materials in Scenedesmus acutus for lipid accumulation and biodiesel production. Appl. Biochem. Biotechnol. 10, 949-964 (2014)

61. Kong, Q.X., Li, L., Martinez, B., Chen, P., Ruan, R.: Culture of microalgae Chlamydomonas reinhardtii in wastewater for biomass feedstock production. Appl. Biochem. Biotechnol. 160, 9-18 (2010)

62. GoP, Pakistan Economic Survey 2012-2013. Government of Pakistan (2013)

63. Bhutto, A.W., Bazmi, A.A., Zahedi, G.: Greener energy: issues and challenges for Pakistan-Biomass energy prospective. Renew. Sustain. Energy Rev. 15, 3207-3219 (2011)

64. EPMC: Data Collection for Preparation of National Study on Privatization of Solid Waste Management in Eight Selected Cities of Pakistan. Engineering Planning and Management Consultants (EPMC), Lahore (1996)

65. Jahangir, T.M., Khuhawar, M.Y., Leghari, S.M., Leghari, A.: Physico-chemical and biological study of Mangho Pir euthermal springs Karachi, Sindh. Pak. Online J. Biol. Sci. 1, 636-639 (2001)

66. Waqar-ul-Haq, Zarina, A., Masud-ul-Hasan, Shameel, M.: Taxonomic study on Volvocophyceae Shameel from certain areas of the Punjab. Pak. J. Bot. 40(2), 833-840 (2008)

67. Korai, A.L., Sahato, G.A., Lashari, K.H., Arbani, S.N.: Biodiversity in relation to physicochemical properties of Keenjhar Lake, Thatta district, Sindh Pakistan. Turk. J. Fish Aquat. Sci. 8, 259-268 (2008)

68. Ali, A., Shinwari, Z.K., Sarim, F.M.: Contribution to the algal flora (Chlorophyta) of fresh waters of district Swat, K.P.K., Pakistan. Pak. J. Bot. 42(5), 3457-3462 (2010)

69. Leghari, S.M.: Bangia atropurpurea (Roth) C.Ag Rhodophyta from Normal and Naltar area near Gilgit, Pakistan. Pak. J. Biol. Sci. 3, 2048-2050 (2000)

70. Musharraf, S.G., Ahmed, M.A., Zehra, N., Kabir, N., Choudhary, M.I., Rahman, A.U.: Biodiesel production from microalgal isolates of southern Pakistan and quantification of FAMEs by GCMS/MS analysis. Chem. Cent. J. 6, 149 (2012)

71. Nazneen, S., Bari, G.A.: Seasonal distribution of phytoplankton in Haleji lake. Pak. J. Agric. Res. 5, 183-189 (1984)

72. Zarina, A., Tariq-Ali, S., Masud-ul-Hasan, Shameel, M.: Taxonomic study of some Euglenoid algae along GT road between Shahdara and Gujranwala. Pak. J. Bot. 6, 3057-3060 (2011)

73. Rehman, A., Shakoori, F.R., Shakoori, A.R.: Seasonal variation in protozoan population in tannery effluents. Pak. J. Zool. 2, 69-76 (2007)

74. Tredici, M.R.: Photobiology of microalgae mass cultures: understanding the Tools for the next green revolution. Biofuels 1(1), 143-162 (2010)

75. Florentinus, A., Hamelinck, C., Lint, S.D., Iersel, S.V.: Worldwide Potential of Aquatic Biomass. Ecofys, Utrecht (2008) 
76. Singh, J., Gu, S.: Commercialization potential of microalgae for biofuels production. Renew. Sustain. Energy Rev. 14, 2596-2610 (2010)

77. Moody, J.W., McGinty, C.M., Quinn, J.C.: Global evaluation of biofuel potential from microalgae. Proc. Natl. Acad. Sci. USA 111, 8691-8696 (2014)

78. Sudhakar, K., Rajesh, M., Premalatha, M.: A mathematical model to assess the potential of Algal Bio-fuels in India. Energy Sour. Part A Recover. Utili. Environ. Eff. 34(12), 1114-1120 (2012)

79. Huntley, M.E., Redalje, D.: $\mathrm{CO}_{2}$ mitigation and renewable oil from photosynthetic microbes: a new appraisal. Mitig. Adapt. Strateg. Glob. Change. 12(4), 573-608 (2007)

80. Ben Amotz, A.: Algae Biomass Summit III, pp. 6-9. Algal Biomass Organization, San Diego (2009)

81. Asif, M.: Sustainable energy options for Pakistan. Renew. Sustain. Energy Rev. 13, 903-909 (2009)

82. Amer, M., Daim, T.U.: Selection of renewable energy technologies for a developing county: a case of Pakistan. Energy Sustain. Dev. 15, 420-435 (2011)

83. Sahir, M.H., Qureshi, A.H.: Assessment of new and renewable energy resources potential and identification of barriers to their significant utilization in Pakistan. Renew. Sustain. Energy Rev. 12(1), 290-298 (2008)
84. Basir, R., Aziz, N., Ahmad, S.S., Wahid, A.: Satellite remote sensing for identification of solar potential sites in Pakistan. Int. J. Basic Appl. Sci. 2, 200-209 (2013)

85. Raja, I.A.: Assessment of solar radiation in Pakistan, Ph.D thesis, University of Strathclyde, Glasgow, U.K. (1992)

86. Zaid, Z.I.: Pakistan renewable energy report. Asian and Pacific centre for transfer of technology of the United Nations-Economic and Social Commission for Asia and the Pacific (ESCAP). $1-53$ (2009)

87. NREL.: Solar map of Pakistan. US National Renewable Energy Laboratory, USA (2010)

88. Smith, V.H., Sturm, B.S.M., de Noyelles, F.J., Billings, S.A.: The ecology of algal biodiesel production. Trends Ecol. Evol. 25, 301-309 (2009)

89. Scott, S.A., Davey, M.P., Dennis, J.S., Horst, I., Howe, C.J., LeaSmith, D.J., Smith, A.G.: Biodiesel from algae: challenges and prospects. Curr. Opin. Biotechnol. 21, 277-286 (2010)

90. Demirbas, A.: Use of algae as biofuel sources. Energy Convers. Manag. 51, 2738-2749 (2010)

91. Maxwell, E. L., Folger, A. G. and Hogg, S. E.: Resource evaluation and site selection for microalgae production systems. SERI/ TR. 215-2484. (1985) 